\title{
Phytochemical and Pharmacological Evaluation of Cyperus odoratus Extract
}

\author{
Ajijul Hakim Alif ${ }^{1}$, Amir Hossain $^{2}$, Md. Akbar Hossain², Tabitha Mitali Madhu², \\ Salma Akter Sumi ${ }^{3}$ and Md. Mustafizur Rahman ${ }^{3}$ \\ ${ }^{1}$ Department of Pharmacy, Dhaka International University, Dhaka-1212, Bangladesh \\ ${ }^{2}$ Department of Pharmacy, ASA University, Bangladesh, Dhaka, Bangladesh \\ ${ }^{3}$ Pharmacy Discipline, Life Science School, Khulna University, Bangladesh
}

(Received: 10 May, 2018; Accepted: 12 July, 2018; Published : 31 July, 2018)

\begin{abstract}
Cyperus odoratus (Family: Cyperaceae) is a 10 to $50 \mathrm{~cm}$ long perennial herb used as traditional medicinal plant in Bangladesh to treat various pathological conditions like piles, tumour and wound. The ethanolic extract of $C$. odoratus (COET) has been evaluated for different bioactivities, for example, antioxidant, analgesic, anthelmintic and cytotoxic activities. Antioxidant activity was investigated by DPPH free radical scavenging assay, analgesic activity was evaluated from 'acetic acid induced writhing inhibition test' in mice, anthelmintic activities was tested by 'time of paralysis and death' assays and cytotoxic activities was observed from the 'brine shrimp lethality bioassay'. Total tannin and phenol contents were also measured by using Folin-Ciocalteu reagent. Phytochemical screening indicated that the presence of alkaloids, tannins, flavonoids, glycosides, proteins, gums, steroids and acidic compounds. In DPPH free radical scavenging assay the extract showed $\mathrm{IC}_{50}$ value of $8.05 \mu \mathrm{g} / \mathrm{ml}$, whereas the standard ascorbic acid showed $31.40 \mu \mathrm{g} / \mathrm{ml}$. The total tannin and phenolic contents were found to be 3.35 and $1.68 \mathrm{mg} \mathrm{GAE} / 100 \mathrm{~g}$ of dried extract, respectively. In acetic acid induced writhing assay, the extract showed 36.23 and $61.32 \%$ writhing inhibition at doses of 250 $\mathrm{mg} / \mathrm{kg}$ and $500 \mathrm{mg} / \mathrm{kg}$ body weight, respectively, whereas standard Diclofenac-Na $(25 \mathrm{mg} / \mathrm{kg})$ showed $70.03 \%$ writhing inhibition. The plant extract showed anthelmintic activity in a dose dependant manner. COET also showed $\mathrm{LD}_{50}$ against brine shrimp nauplii at $11.344 \mu \mathrm{g} / \mathrm{mL}$. After observing all preliminary biological data, it has been confirmed that the plant has antioxidant, analgesic, cytotoxic and anthelmintic properties.
\end{abstract}

Key words Cyperus odoratus, antioxidant, analgesic, anthelmintic, cytotoxic.

\section{Introduction}

Medicinal plants have long history of use by human being for the cure of various ailments dating back to primitive age, probably when people observed the animal behaviour to utilize certain plant's parts during their sickness (Sofowara, 1982; Hill, 1989). Medicinal plants always have played a major role in human health development and in disease control and cure. In recent times, it has been estimated that at least $80 \%$ of world population is reliant on medicinal plants rather natural medicine sources to cure ailments and improve health (Kaur and Jaggi, 2010). The World Health Organization (WHO) also provided similar data at early 2000s (Alves and Rosa, 2005). Perhaps, it is the fact that natural products have more 'drug like and biological characteristics' than most of the synthetic drugs, with fewer side effects that make them suitable candidate for therapeutic use (Minhajur et al., 2011). Moreover, about $25 \%$ pharmaceutically formulated drugs are derived from natural origin (Islam et al., 2016). As expected, researches on natural products are increasing day by day. Bangladesh has wide range of tropical and agro growing conditions that are 
advantageous to introduce and domestication of new plant varieties (Hossain et al., 2013). It is a perfect place for $C$. odoratus to grow and they are common in here.

C. odoratus is a perennial grass-like sedge. It is a monocotyledonous graminoid flowering plant which belongs to Cyperaceae family. C. odoratus has fibrous root along with slender and scaly creeping rhizomes, arises singly from the triquetras tubers with dense tuft of 10 to $60 \mathrm{~cm}$. It has grass-like leaves, having no hair but easily distinguishable from grass. This grass grows in tropical, subtropical and temperate regions. It is prevalent in North America, Japan, Korea and Russia (Maximowicz and Mém, 1859).

To elucidate the pharmacological activities of $C$. odoratus, three studies were commissioned recently. Three compounds, 3,4-dimethoxy benzoic acid (1), 4hydroxybenzoic acid (2) and piceatannol (3) were isolated from the active ethyl acetate soluble fraction of $C$. odoratus and was investigated for antioxidant property using DPPH scavenging assay. (Lee et al., 2008). C. odoratus showed declined proliferation of human hepatocellular carcinoma (cell line used: Hep3B) by inducing apoptosis and arresting the G0/G1 phase of cell cycle (Pham et al., 2016). C. odoratus also gave $57.3 \%$ in-vitro pancreatic lipase inhibitory activity (Sharma et al., 2005). Traditionally, this grass is used to treat wounds, piles and tumours in Bangladesh by traditional medicinal practitioners (Rahmatullah et al., 2009).

Since, there is no reported data on analgesic, anthelmintic, cytotoxic activity, and antioxidant properties and total phenolic and tannin content of $C$. odoratus, the present study was undertaken to elucidate and evaluate these bioactivities to justify its medicinal use.

\section{Materials and Methods}

Plant collection and extraction: C. odoratus plant was procured from Sataish area of Gazipur district, Bangladesh in June, 2017 and experts at Bangladesh National Herbarium, Mirpur, Dhaka has identified it (voucher specimen no.: 45931). The whole plant was taken except the root and properly washed with fresh water to remove dirt, was shade dried for few days. The plant was then crushed into coarse powder with grinding machine. The powdered plant materials were stored at room temperature for further use. Five hundred gram of the dried-crushed materials were then soaked with about $1500 \mathrm{ml}$ ethanol in an amber glass container. This mixture was occasionally shaken and stirred for 7 days and eventually was filtered with a piece of clean white cotton. Then it was again put through filtration using Whatman No. 1 filter paper. The filtrate was evaporated and dried at room temperature with continuous air flow. Total yield of COET was $2.05 \%$.

Chemicals: Sodium carbonate and FolinCiocalteus's reagent were obtained from Merck (Damstadt, Germany), potassium dichromate, gallic acid (GA), ascorbic acid (AA), $\mathrm{AlCl}_{3}, \mathrm{H}_{2} \mathrm{SO}_{4}$, Nitric acid, $\mathrm{NaOH}$, DMSO, EDTA, Diclofenac-Na, sodium nitrite, tween-80 and $\mathrm{FeCl}_{3}$ were purchased from the Sigma Chemical Co.

Phytochemical screening: Standard chemical reagents were used to identify and categorize the chemical constitutes of COET using some positive control processes, for example, reducing sugar with Fehling's Solution and Benedict's reagent, combined reducing sugar with Fehling's Solution, glycosides with $\mathrm{NaOH}$ solution, Protein-Xanthoprotein with $\mathrm{HNO}_{3}$, flavonoids with concentrated $\mathrm{H}_{2} \mathrm{SO}_{4}$, dilute $\mathrm{HCl}$ and dilute $\mathrm{NaOH}$, Tarpenoid with $\mathrm{H}_{2} \mathrm{SO}_{4}$, acidic compound with $\mathrm{NaHCO}_{3}$ solution, alkaloid with Mayer's and Dragendroff's reagent, saponins with distilled water and tannin with $\mathrm{FeCl}_{3}$ and $\mathrm{K}_{2} \mathrm{Cr}_{2} \mathrm{O}_{7}$ solution (Ghani, 1995).

DPPH free radical scavenging assay: Quantitative antioxidant activity of COET was estimated by DPPH (2, 2-diphenyl-1-picrylhydrazyl) free radical scavenging assay (Choi et al., 2000). In this method, $0.004 \%$ (w/v) DPPH solution was prepared in ethanol and $3 \mathrm{ml}$ of it was mixed with 1 $\mathrm{mL}$ ethanolic crude extract at a different concentration. Subsequently, the mixture was vigorously shaken and kept in a dark place at room temperature for about 30 minutes. UV absorbance 
was measured at $517 \mathrm{~nm}$. Percentage of scavenging activity was measured by following equation:

$\%$ DPPH free radical scavenging activity $=\left[\left(\mathrm{A}_{0}-\right.\right.$

$$
\left.\left.\mathrm{A}_{1}\right) / \mathrm{A}_{0}\right] \times 100
$$

Here, $A_{0}$ is the absorbance of control, and $A_{1}$ is the absorbance of $C$. odoratus/positive control. The $\%$ scavenging activity was then plotted against $\log$ concentration and a graph for $\mathrm{IC}_{50}$ was calculated.

Estimation of total phenolics: Total phenolic content of COET was determined by Folin-Ciocalteu technique (Borah et al. 2011). 2 ml Folin-Ciocalteu reagent was diluted 10 times with $2 \mathrm{ml} \mathrm{Na}_{2} \mathrm{CO}_{3}$ (75 $\mathrm{g} / \mathrm{l})$ and water $(1: 10 \mathrm{v} / \mathrm{v})$ and an aliquot of COET or positive control was mixed with this. To develop colour, the tubes were shaken for 15 seconds and then the mixtures were allowed to stand 20 minutes at room temperature. UV absorbance was measured at $750 \mathrm{~nm}$. COET or positive control was evaluated at $0.1 \mathrm{mg} / \mathrm{ml}$ concentration. Gallic acid equivalent, GAE (mg of GA/g of dried plant extract) was used to express total phenolic content. Then a gallic acid standard calibration curve was developed with a positive control curve equation of $\mathrm{y}=0.062 \mathrm{x}-$ $0.0153, R^{2}=0.982$

Determination of total tannins: Total tannin content of COET was determined by using FolinCiocalteu (FC) reagent (Marinova et al., 2005). To begin the process, $0.1 \mathrm{ml}$ COET (positive control) was added to $0.5 \mathrm{ml} \mathrm{FC}$ reagent and $7.5 \mathrm{ml}$ distilled water. This preparation was shaken and kept for 5 minutes. Then $1 \mathrm{ml} 35 \% \mathrm{Na}_{2} \mathrm{CO}_{3}$ solution was added by following a dilution with $10 \mathrm{ml}$ distilled water. This preparation was then kept at room temperature for 30 minutes. UV absorbance was measured at 725 nm against blank after 30 minutes. Gallic acid equivalent, GAE (mg of $\mathrm{GA} / \mathrm{g}$ of dried plant extract) was used to express total tannin content. Then gallic acid standard calibration curve was developed and positive control curve equation was $\mathrm{y}=0.0209 \mathrm{x}$ $0.0214, \mathrm{R}^{2}=0.904$.

Acetic acid induced writhing inhibition test: To assess the analgesic activity of COET, acetic acid induced writhing method was rendered on mice (Ahmed et al,. 2004). Swiss-albino mice of any sex $(\mathrm{n}=5)$ weighing $25-40 \mathrm{~g}$ were taken as study subjects. All subjects were unfed for $2 \mathrm{hrs}$ prior to commencing the experiment. Subjects were divided into four groups. $1 \%$ tween- 80 solution in water $(10$ $\mathrm{ml} / \mathrm{kg}$ ) was given to Group-I as the control, Group-II received Diclofenac-Na as positive control at 25 $\mathrm{mg} / \mathrm{kg}$ body weight dose. The other two groups, Groups-III and -IV were treated with COET dose of 250 and $500 \mathrm{mg} / \mathrm{kg}$ body weight, respectively. 30 minutes later, $0.7 \%$ acetic acid was intra-peritoneally injected into subject animals. 5 minutes later writhing number was counted for the period of 15 minutes.

Evaluation of anthelmintic activity: Anthelmintic activity of COET was investigated on live adult earth worm Pheretima posthuma (Ghosh et al., 2005). Four (4) different groups were made having four (4) parasites in each of them. COET concentrations of 25 and $50 \mathrm{mg} / \mathrm{ml}$ and standard solution (i.e., standard Albendazole) of $15 \mathrm{mg} / \mathrm{ml}$ were prepared in PBS. They were then transferred to petri dishes. $0.1 \%$ tween-80 in PBS was used to treat the control group. Every petri dish had four (4) parasites and their activities were observed. The paralysis time (i.e., when the parasites had no movement without robust shaking) and the death time (i.e., when the parasites did not show any movement or response upon vigorous shaking, treatment with warm water $\left(50^{\circ} \mathrm{C}\right)$ or external stimuli) were recorded,. As compared to control, the time required for paralysis and death of parasites were used to assess the anthelmintic activity of COET.

Brine shrimp lethality bioassay: Brine shrimp lethality bioassay was employed to evaluate the cytotoxic activity of COET (McLaughlin et al., 1998). Artemia was chosen to convey this test. Artificial sea water was produced by using $3.8 \%$ $\mathrm{NaCl}$ solution and the brine shrimp eggs were hatched for 1 day ( $24 \mathrm{hrs}$ ) to mature the shrimp (i.e., nauplii). Stock solution of $5 \mathrm{ml}$ was serially diluted to make concentrations $320,160,80,40,20,10$ and 5 $\mu \mathrm{g} / \mathrm{mL} .5 \mathrm{ml}$ stock solution of vincristine sulphate (positive control) was serially diluted to make concentrations 5, 2.5, 1.25, 0.625 and $0.325 \mu \mathrm{g} / \mathrm{ml}$. Ten (10) different test tubes were taken and ten (10) 
nauplii were taken in each of them with volume adjusted to $10 \mathrm{ml}$ with sea water. The concentration of DMSO was kept at $10 \mu \mathrm{l} / \mathrm{ml}$. After 1 day ( $24 \mathrm{hrs}$ ), the test tubes were checked against light to count the number of alive shrimps. Lastly, the $\mathrm{LC}_{50}$ values were measured from Probit Analysis Chart. Probit Analysis Chart was done with "LdP line software" to measure the $\mathrm{LC}_{50}$ values (Bauer et al., 1966).

Statistical analysis: All analyses were double checked and passed in two replications. Mean \pm SEM was used to present data. All experimental parameters were evaluated for their significance level by correlation and regression analysis, the t-tests $(\mathrm{P}<0.05)$ was used. Microsoft Excel 2016 was used for both statistical analysis and graphical presentation.

\section{Results}

Phytochemical screening: Phytochemical screening of $C$. odoratus plant extract (COET) showed the presence of alkaloids, tannins, flavonoids, glycosides, proteins, gums, steroids and acidic compounds, which are summarized in Table 1.

Total phenolic and tannin content: Gallic acid equivalent was used to determine and express total phenolic and tannin contents of COET (Figure 2). Total phenolic and total tannin content were $1.68 \mathrm{~g}$ GAE/100 $\mathrm{g}$ and $3.35 \mathrm{~g} \mathrm{GAE} / 100 \mathrm{~g}$, respectively of $C$. odoratus plant extract as represented in Table 2.

Table 1. Result of phytochemical screening of ethanol extract of $C$. odoratus.

\begin{tabular}{lc}
\hline Phytochemical Group & Result \\
\hline Reducing sugar & - \\
Combined reducing sugar & - \\
Tannins & + \\
Flavonoids & + \\
Saponin & - \\
Gums & + \\
Steroids & + \\
Alkaloids & + \\
Glycoside & + \\
Proteins & + \\
Acidic compounds & + \\
\hline
\end{tabular}

$(+)=$ present $;(-)=$ absent

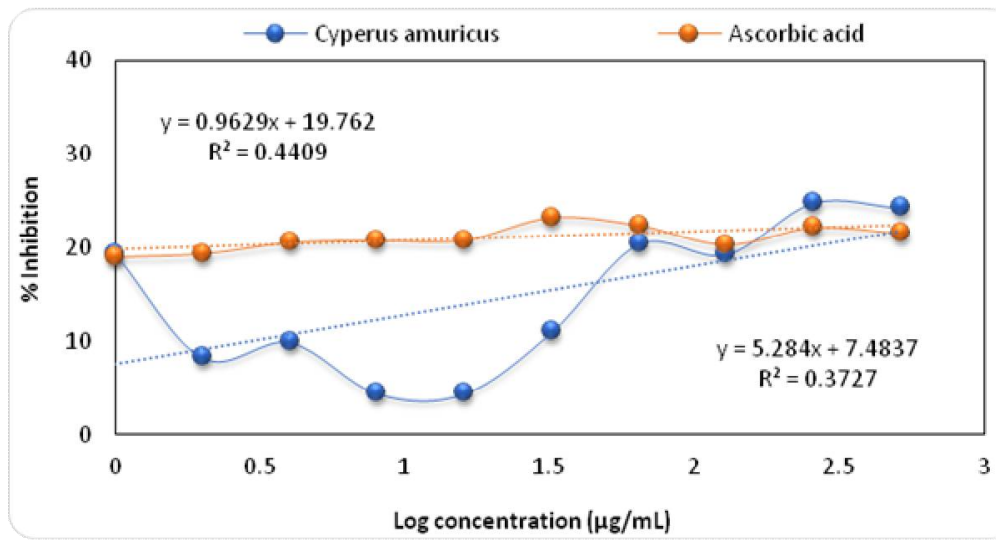

Figure 1. Comparison of $\%$ inhibition vs. log concentration graph for standard (ascorbic acid) vs. Cyperus odoratus ethanolic extract 
Analgesic activity: COET exhibits a significant inhibition of writhing reflex as signified by the result of analgesic activity. COET reduced writhing by $36.23 \%$ and $61.32 \%$ at $250 \mathrm{mg} / \mathrm{kg}$ and $500 \mathrm{mg} / \mathrm{kg}$ doses, respectively. The positive control (Diclofenac$\mathrm{Na}$ ) showed $70.03 \%$ writhing inhibition at a dose of $25 \mathrm{mg} / \mathrm{kg}$ body weight (Table 3 ).

DPPH free radical scavenging activity: Quantitative antioxidant activity of COET was performed by DPPH free radical scavenging assay, where the $\mathrm{IC}_{50}$ value for scavenging free radicals of the extract was $8.05 \mu \mathrm{g} / \mathrm{ml}$, whereas standard ascorbic acid showed the $\mathrm{IC}_{50}$ value of $31.40 \mu \mathrm{g} / \mathrm{ml}$ (Figure 1).

Table 2. Phenolic and tannin content of ethanol extract of $C$. odoratus.

\begin{tabular}{lc}
\hline Polyphenolic compounds & Content \\
\hline Total phenol & $1.68 \pm 0.001$ \\
Total tannin & $3.35 \pm 0.001$ \\
\hline
\end{tabular}

Here, each value represents the average of two analysis \pm standard error of mean expressed in terms of gm GAE /100 gm dried plant extract.

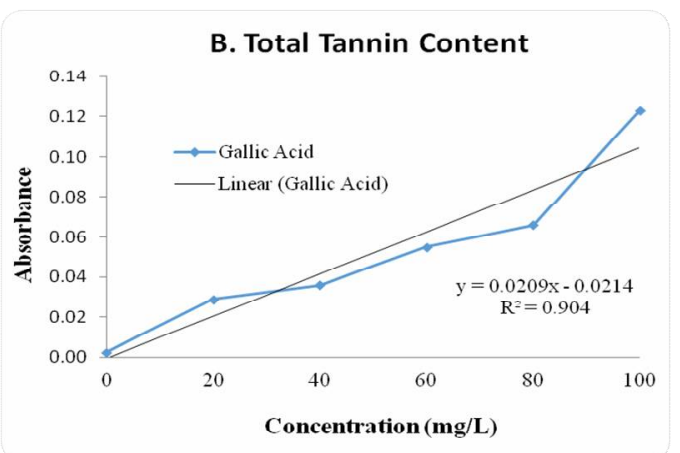

Anthelmintic activity: The anthelmintic activity of COET and standard Albendazole are shown in Table 4 and Figure 3. COET caused paralysis at approximately 70 minute and 44 minute at concentrations of 25 and $50 \mathrm{mg} / \mathrm{ml}$, whereas the approximate death times were observed at 72 minute and 46 minute at respective concentration. Standard Albendazole also showed paralysis at around $18 \mathrm{~min}$ and death at 26 minute for $15 \mathrm{mg} / \mathrm{ml}$ concentration. Extract showed more effectiveness at higher concentration $(50 \mathrm{mg} / \mathrm{ml})$ against Pheretima posthuma.

Brine Shrimp Lethality Bioassay: The percent mortality of the nauplii caused by both the plant extract and the positive control (Vincristine Sulphate) is expressed in Figure 4. The $\mathrm{LD}_{50}$ of sample as well as positive control was calculated by Probit analysis software (LdP Line software, USA). The $\mathrm{LD}_{50}$ for COET was found to be $11.344 \mu \mathrm{g} / \mathrm{ml}$ whereas the positive control (Vincristine Sulphate) showed $\mathrm{LD}_{50}$ at $0.7158 \mu \mathrm{g} / \mathrm{ml}$ (Table 4).

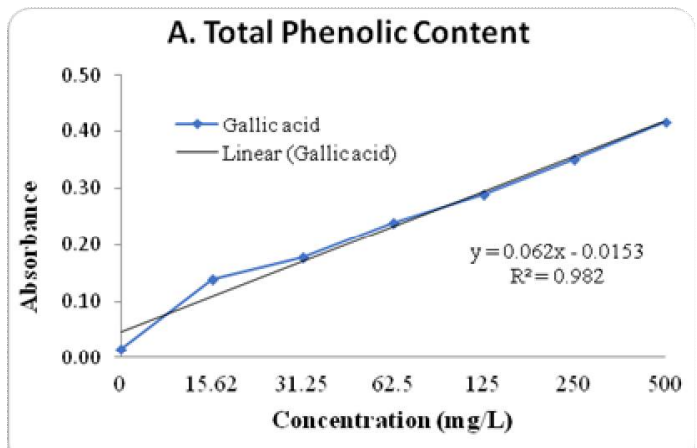

Figure 2. Determination of total phenolic (A) and total tannin (B) contents.

Table 3. Analgesic activity of COET in acetic acid induced pain in mice model.

\begin{tabular}{lccc}
\hline Treatment $(n=5)$ & Dose $(\mathrm{mg} / \mathrm{kg})$ & Mean writhes $(\mathrm{no})$ & $\%$ Inhibition \\
\hline Control & $1 \%$ Tween-80 & $23.4 \pm 3.14$ & -- \\
Diclofenac-Na & 25 & $7 \pm 1.04^{*}$ & 70.03 \\
Extract 250 & 250 & $16.6 \pm 1.4^{* *}$ & 36.23 \\
Extract 500 & 500 & $11.6 \pm 0.7 * * *$ & 61.32 \\
\hline
\end{tabular}

Values are expressed as mean $\pm \mathrm{SEM}, \mathrm{SEM}=$ Standard error for mean. $n=$ number of mice $(5), * \mathrm{P}=0.0011, * * \mathrm{P}=0.0844$ and $* * * \mathrm{P}=0.0064$ vs. control, Student's t-test. 
Table 4. Anthelmintic activity of COET.

\begin{tabular}{|c|c|c|c|c|c|}
\hline $\begin{array}{l}\text { Treatments } \\
\text { Concentration } \\
(\mathrm{mg} / \mathrm{ml})\end{array}$ & Worm No. & $\begin{array}{l}\text { Time taken for } \\
\text { paralysis } \\
\text { (min) }\end{array}$ & $\begin{array}{l}\text { Mean time of } \\
\text { paralysis } \\
(\min \pm \mathrm{SD})\end{array}$ & $\begin{array}{l}\text { Time taken for } \\
\text { death (min) }\end{array}$ & $\begin{array}{c}\text { Mean time of } \\
\text { death (min. } \pm \text { SD) }\end{array}$ \\
\hline \multirow{4}{*}{$\begin{array}{l}\text { Control } \\
0.1 \% \text { Tween-80 in } \\
\text { PBS }\end{array}$} & $\mathrm{C} 1$ & - & \multirow{4}{*}{ - } & \multirow{4}{*}{ - } & \multirow{4}{*}{ - } \\
\hline & $\mathrm{C} 2$ & - & & & \\
\hline & $\mathrm{C} 3$ & - & & & \\
\hline & $\mathrm{C} 4$ & - & & & \\
\hline \multirow{4}{*}{$\begin{array}{l}\text { Standard } \\
\text { Albendazole } \\
15\end{array}$} & S1 & 15.25 & \multirow{4}{*}{$18.01 \pm 2.45$} & 23.32 & \multirow{4}{*}{$26.12 \pm 2.22$} \\
\hline & S2 & 18.45 & & 27.55 & \\
\hline & S3 & 21.11 & & 28.22 & \\
\hline & S4 & 17.21 & & 25.39 & \\
\hline \multirow{4}{*}{$\begin{array}{l}\text { Extract } \\
25\end{array}$} & $\mathrm{~T} 1$ & 65.4 & \multirow{4}{*}{$70.19 \pm 3.55$} & 67.26 & \multirow{4}{*}{$72.38 \pm 3.60$} \\
\hline & $\mathrm{T} 2$ & 68.48 & & 71.19 & \\
\hline & $\mathrm{T} 3$ & 73.19 & & 74.21 & \\
\hline & $\mathrm{T} 4$ & 72.08 & & 75.29 & \\
\hline \multirow{4}{*}{$\begin{array}{l}\text { Extract } \\
50\end{array}$} & $\mathrm{~T} 1$ & 30.21 & \multirow{4}{*}{$44.04 \pm 9.77$} & 31.42 & \multirow{4}{*}{$46.40 \pm 10.84$} \\
\hline & $\mathrm{T} 2$ & 44.47 & & 47.49 & \\
\hline & $\mathrm{T} 3$ & 46.28 & & 49.45 & \\
\hline & $\mathrm{T} 4$ & 53.56 & & 57.25 & \\
\hline
\end{tabular}

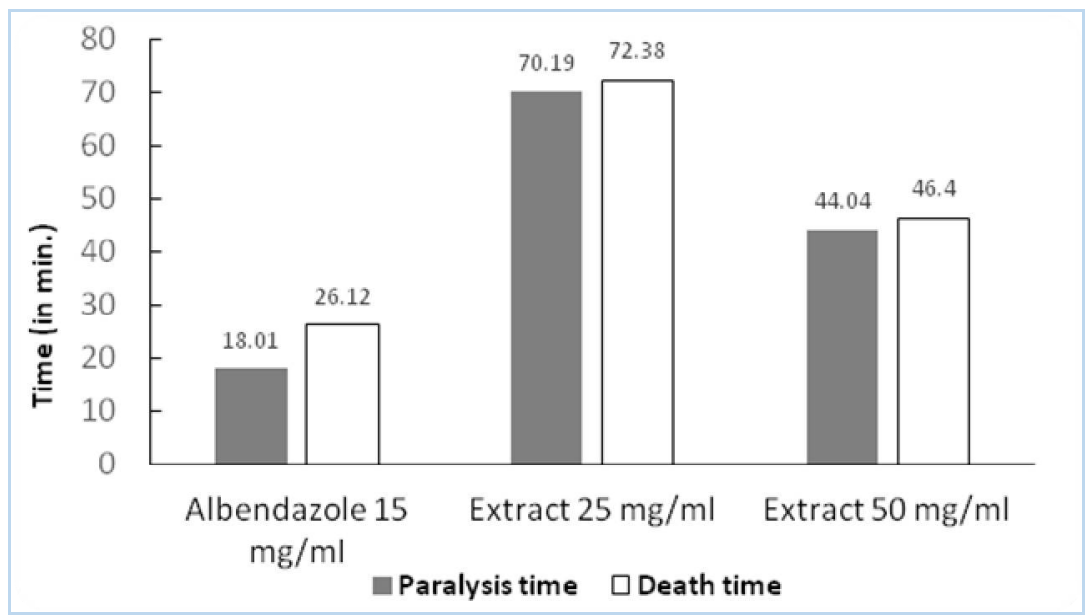

Figure 3. Determination of anthelmintic activity of COET through paralysis time and death time.

Table 5. $\mathrm{LD}_{\mathbf{5 0}}$ for extract and standard with lower and upper limit.

\begin{tabular}{lccc}
\hline Treatment & Conc. $(\mu \mathrm{g} / \mathrm{ml})$ & Lower limit $(\mu \mathrm{g} / \mathrm{ml})$ & $\begin{array}{c}\text { Upper limit } \\
(\mu \mathrm{g} / \mathrm{ml})\end{array}$ \\
\hline Extract & 11.344 & 6.1642 & 16.7322 \\
Standard & 0.7158 & 0.4123 & 1.0293 \\
\hline
\end{tabular}



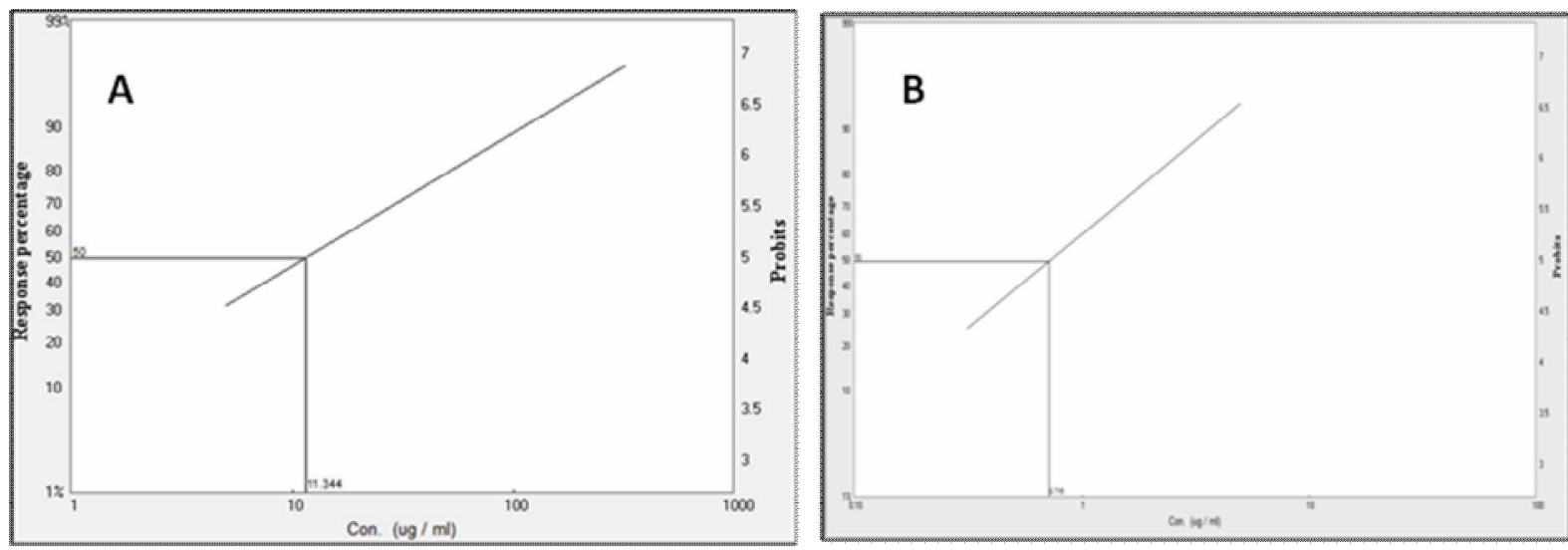

Figure 4. Graphical representation of brine shrimp lethality bioassay and $\mathrm{LD}_{50}$ for COET (A) and positive control (i.e., Vincristine sulphate) (B) by LdP line software.

\section{Discussion}

Antioxidant activity is one of the most important pharmacological properties of plants. To test the free radical scavenging activity or the antioxidant activity of plant extracts and foods a stable free radical, DPPH is widely used (Porto et al., 2000; Soares et al., 1997), which is readily scavenged by antioxidants (Lu and Yeap Foo, 2001). The scavenging ability of the extract was found to be concentration-dependent and expressed as $\mathrm{IC}_{50}$ (i.e., sample concentration required to decrease the initial concentration of DPPH by 50\%) values. A higher antioxidant activity is indicated by a lower $\mathrm{IC}_{50}$ value. In this study, the ethanol extract of $C$. odoratus showed an acceptable $\mathrm{IC}_{50}$ value, which is compared to standard ascorbic acid (Figure 1) and it indicates the presence antioxidant components in the plant extract. The result also suggests that the plant contains phytochemical constituents that are capable of donating hydrogen in order to protect the cell from potential damage.

Plant phenolic compounds such as flavonoids, phenolic acids, and tannins present in the fruits and vegetables have potential biological activities including antiatherosclerotic, anticancer and antiinflammatory activities and such activities might be associated with their antioxidant properties (Chung et al., 1998). Plant phenolic compunds containing hydroxyl groups have a good scavenging capacity (Kahkonen et al., 1999; Naczk and Shahidi, 2004).
The result (1.68 g GAE/100g of dried extract) proved that the extract possesses phenolic compounds containing hydroxyl groups.

Bitter plants contain polyphenols such as tannins, which have astringent properties and thus they can bind to protein molecules to precipitate or shrink them. Tannins contain sufficient hydroxyl groups and other free radicals for instance carboxyl and they bind proteins and other macromolecules. These free radicals protect cell damage (AfifyAel-M. et al., 2012). Some studies specify that tannins are effective against ulcerated or inflamed tissues and they also possess a good anticancer activity (Ruch et al., 1989; Motar et al., 1985). Our studied result suggests that the extract contains considerable amount of tannins that may be a source of free radicals to protect the cell from death and satisfy the possible mechanism of plants' free radical scavenging properties.

Pathological condition such as tissue injury induced pain results in the local release of prostaglandins, cytokinins, leukotrienes etc. that act on the nerve terminals in both activating them directly and enhancing their sensitivity to other stimulations (Kanodia and Das, 2008; Goldstein et al., 1970). Intraperitoneal administration of acetic acid produces pain by consequent abdominal writhing due to the release of mediators like prostaglandin E2 and other lipooxygenase products (Sulaiman et al., 2008). There are mainly two 
prostaglandins, prostacyclines (PGI2) and prostaglandin E (PG-E), which are responsible for pain sensation due to the excitation of A $\delta$-nerve fibers (Lourens et al., 2004). Thus, ethanol plant extract of $C$. odoratus may produce analgesic activity due to the inhibition of prostaglandin synthesis by blocking of lipooxygenase and cyclooxygenase activities. In this study, extract of $C$. odoratus showed a comparable writhing inhibition to Diclofenac-Na, standard analgesic drug. The extract showed analgesic activity in a dose dependent manner.

The extracts showed anthelmintic activity in a dose-dependent manner. Evaluation of anthelmintic activity was compared with reference standard Albendazole. Phytochemical screening revealed that the presence of tannins along with other chemical constituents contained within them. Tannins have been reported to be responsible for anthelmintic activities (Niezen et al., 1995; Shrestha et al., 2009), as they can cause the death of parasites upon binding to free proteins in the gastrointestinal tract of host animal (Athanasiadou et al., 2001) or glycoprotein on the cuticle of the parasite (Thompson et al., 1995).

The brine shrimp lethality bio assay is a rapid, inexpensive and simple bioassay for testing plant extract's bioactivity, which in most cases correlates reasonably well with cytotoxic and anti-tumour properties (McLaughlin et al., 1993). This assay was proposed by Michael et al. in 1956 and developed by Vanhaecke and co-workers in 1981 and improved by Sleet and Brendel in 1983. The brine shrimp lethality bioassay has been widely used in the primary screening of the crude extracts and the isolated compounds to assess the toxicity towards brine shrimps (Meyer et al., 1982). This assay is recommended for the detection of antitumour and pesticidal compounds due to its simplicity and low cost (Mazid et al., 2008). The assay is a useful tool for preliminary assessment of toxicity. Fungal toxins, plant extract toxicity, heavy metals, pesticides and cytotoxicity can be detected with the help of this assay (Harwig and Scott, 1971; McLaughlin et al., 1991; Pelka et al., 2000). Bioactive compounds can be isolated from plant extracts using brine shrimp assay (Sam, 1993). The significant lethality of brine shrimp due to extracts of Cyperus odoratus is an indicative of the presence of potent cytotoxic components.

\section{Conclusion}

The present study reveals that the ethanol extract of $C$. odoratus plant possess antioxidant activity and significant analgesic activity as well as cytotoxic and anthelmintic activity which justifies its uses in folk medicine. These preliminary studies do not describe the actual mechanism for various pharmacological actions reported in this manuscript. However, more extensive studies (including isolation and identification of active compounds and in-depth pharmacological mechanistic assays) are required to determine the exact mechanism of action of the extract and its active compound(s) to authenticate it as a potent antioxidant, analgesic, cytotoxic and anthelmintic agent.

\section{Declaration of interest}

The authors declare no conflict of interest.

\section{Acknowledgements}

The authors are grateful to Department of Pharmacy, ASA University Bangladesh and Dhaka International University for providing necessary instrumental facilities and others supports. We are also grateful to the Director of Bangladesh National Herbarium, Dr. Hosne Ara, for her kind assistance in deposition of voucher specimens.

\section{Reference}

AfifyAel-M, El-Beltagi, H.S., El-Salam, S.M. and Omran, A.A. 2012. Biochemical changes in phenols, flavonoids, tannins, vitamin E, $\beta$-carotene and antioxidant activity during soaking of three white sorghum varieties. Asian Pac. J. Trop. Biomed. 2, 203-209.

Ahmed, F., Selim, M.S.T., Das, A.K. and Choudhuri, M.S.K. 2003. Anti-inflammatory and antinociceptive activities of Lippia nodiflora Linn. Pharmazie. 59, 329-333. 
Alves, R.R.N. and Rosa, I.L. 2005. Why study the use of animal products in traditional medicines? $J$. Ethnobiol. Ethnomed. 1, 1-5.

Athanasiadou, S., Kyriazakis, I., Jackson, F. and Coop, R.L. 2001. Direct anthelmintic effects of condensed tannins towards different gastrointestinal nematodes of sheep: in vitro and in vivo studies. Vet. Parasitol. 99, 205-219.

Bauer, A.W., Kirby, W.M., Sherris, J.C. and Turck, M. 1966. Antibiotic susceptibility testing by a positive controlized single disk method. Am. J. Clin. Pathol. 45, 493-496.

Borah, A., Yadav, R.N.S. and Uni, B.G. 2011. In-vitro antioxidant and free radical scavenging activity of Alternanthera sessilis. Int. J. Pharm. Sci. Rev. Res. 2 , 1502-1506.

Choi, H.Y., Jhun, E.J., Lim, B.O., Chung, I. M., Kyung, S. H. and Park, D. K. 2000. Application of flow injection-chemiluminescence to the study of radical scavenging activity in plants. Phytother. Res. 14, 250253.

Chung, K.T., Wong, T.Y., Wei, C.I., Huang, Y.W. and Lin, Y. 1998. Tannins and human health: a review. Crit. Rev. Food Sci. Nutr. 38, 421-464.

Ghani, A. 2003. Medicinal Plants of Bangladesh with Chemical Constituents and Uses. $2^{\text {nd }}$ ed. Asiatic Soc. Bangladesh, Dhaka. pp. 603.

Ghosh, T., Maity, T.K., Bose, A. and Dash, G.K. 2005. Anthelmintic activity of Bacopa monierri. Indian J. Nat. Products. 21, 16-19.

Goldstein, A., Aronow, L. and Kalman, S.M. 1970. Principles of drug action. The basis of pharmacology. J. Med. Chem. 13, 337-337.

Harwig, J. and Scott, P.M. 1971. Brine shrimp (Artemia salina L.) larvae as a screening system for fungal toxins. Appl. Microbiol. 21, 1011-1016.

Hill, A.F. 1989. Economic Botany: A Text Book of Useful Plants and Plant Products, $2^{\text {nd }}$ ed. McGraw Hill Book Company, Inc., New York, pp. 560.

Hossain, H., Jahan, I.A., Islam, H.S., Kanti, D.S., Arpona, H. and Arif, A. 2013. Phytochemical screening and anti-nociceptive properties of the ethanolic leaf extract of Trema cannabina Lour. Adv. Pharm. Bull. 3, 103-108.

Islam, M.T., Mata, A.M.O.F., Aguiar, R.P.S., Paz, M.F.C.J., Alencar, M.V.O.B. and Melo-Cavalcante, A.A.C. 2016. Therapeutic potential of essential oils focusing on diterpens. Phytother. Res. 30, 1420-1444.
Kahkonen, M.P., Hopia, A.I., Vuorela, H.J., Rauha, J.P., Pihlaja, K., Kujala, T.S. and Heinonen, M. 1999. Antioxidant activity of plant extracts containing phenolic compounds. J. Agri. Food Chem. 47, 39543962.

Kanodia, L. and Das, S. 2008. A comparative study of analgesic property of whole plant and fruit extracts of Fragaria vesca in experimental animal models. Bangladesh J. Pharmacol.. 4, 35-38.

Kaur, S. and Jaggi, R.K. 2010. Antinociceptive activity of chronic administration of different extracts of Terminalia bellerica Roxb. and Terminalia chebula Retz. fruits. Indian J. Exp. Biol. 48, 925-930.

Lee, S.I., Choi, H., Jeon, H., Baek, N.I., Kim, S., Kim, H.J., Cho, C.H., Ahn, H.C., Yang, J.H., Chae, B.S., Lim. J.Y., Eun, J.S. and Kim, D.K. 2008. Antioxidant phenolic components from the whole plant extract of Cyperus amuricus Max. Korean J. Pharmacognosy. 39, 233-236.

Lourens, A.C., Reddy, D., Baser, K.H., Viljoen, A.M. and Van, V.S.F. 2004. In-vitro biological activity and essential oil composition of four indigenous South African Helichrysum species. J. Ethnopharmacol. 95, 253-258.

Lu, Y. and Foo, L.Y. 2001. Antioxidant activities of polyphenols from sage (Salvia officinalis) Food Chem. 75, 197-202.

Marinova, D., Ribarova, F. and Atanassova, M. 2005. Total phenolics and total flavonoids in Bulgarian fruits and vegetables. J. Univ. Chem. Technol. Metallurgy. 40, 255-260.

Maximowicz and Mém: Acad. Imp. Sci. St.-Pétersbourg Divers Savans 9. Prim. Fl. Amur. 296, 1859.

Mazid, M.A., Datta, B.K., Nahar, L. and Sarker, S.D. 2008. Assessment of anti-bacterial activity and brine shrimp toxicity of two Polygonum species. Ars. Pharm. 49, 127-134.

McLaughlin, J.L., C.J. Chang, C.J. and Smith, D.L. 1991. Bench-Top Bioassays for the Discovery of Bioactive Natural Products: An Update. In: Studies in Natural Products Chemistry, Rhaman, A.U. (Ed.). Elsevier, Oxford, pp: 383-409.

McLaughlin, J.L., Chang, C.J. and Smith, D.L. 1993. Simple bench-top bioassays (brine shrimp and potato discs) for the discovery of plant antitumor compounds. Am. Chem. Soc. ACS Sympos. Ser., 534, 112-134.

McLaughlin, J.L., and Rogers, L.L. 1998. The use of biological assay to evaluate botanicals. Drug Info. J., 32, 513-524. 
Meyer, B.N., Ferrigni, N.R., Putnam, J.E., Jacobsen, J.B., Nicholsand, D.E. and Mclaughlin, J.L. 1982. Brine shrimp; a convenient general bioassay for active plant constituents. Plant Med. 45, 31-34.

Michael, A.S., Thompson, C.G. and Abramovitz, M. 1956. Artemia salina as a test organism for a bioassay. Science, 123, 464.

Olajide, O.A., Aderogba, M.A., Adedapo, A.D. and Makinde, J.M.1985. Effects of Anacardium occidentale stem bark extract on in-vivo inflammatory models. J. Ethnopharm. 95, 139-142.

Naczk, M. and Shahidi, F. 2004. Extraction and analysis of phenolics in food. J. Chromatogr. A. 1054, 95-111.

Niezen, J.H., Waghorn, T.S., Charleston, W.A. and Waghorn, G.C. 1995. Growth and gastrointestinal nematode parasitism in lambs grazing either lucerne (Medicago sativa) or sulla (Hedysarum coronarium) which contains condensed tannins. J. Agri. Sci. 125, 281-289.

Pham, H.H., Seong, Y., Oh, C.W. and Kim, G.D. 2016. The herbal medicine Cyperus amuricus inhibits proliferation of human hepatocellular carcinoma Hep3B cells by inducing apoptosis and arrest at the G0/G1 cell cycle phase. Int. J. Oncol. 49, 2046-2054.

Pelka, M., Danzl, C.,Distler, W. and Petschelt, A. 2000. A new screening test for toxicity testing of dental materials. J. Dent. 28, 341-345.

Porto C.D., Calligaris S., Celloti E. and Nicoli M.C. 2000. Antiradical properties of commercial cognacs assessed by the DPPH(*) test. J. Agric. Food Chem. 48, 4241-4245.

Minhajur, R.M., Alam, M.M., Shahriar, M., Moghal, M.R. and Siddiqui, R. 2011. The antibacterial activity and brine shrimp lethality bioassay of leaf extracts of Stephania japonica (Akanadi). Bang. J. Microbiol. 28, 52-56.

Rahmatullah, M., Ferdausi, D., Mollik, A.H., Jahan, R., Chowdhury, M.H. and Haque, W.M. 2010. A survey of medicinal plants used by Kavirajes of Chalna area, Khulna district, Bangladesh. Afr. J. Tradit. Complement Altern. Med. 7, 91-97.
Ruch, R.J., Cheng, S.J. and Klaunig, J.E. 1989. Prevention of cytotoxicity and inhibition of intercellular communication by antioxidant catechins isolated from Chinese green tea. Carcinogen. 10, 1003-1008.

Sam, T.W. 1993. Toxicity Testing Using the Brine Shrimp: Artemia salina. In: Bioactive Natural Products Detection, Isolation, and Structural Determination, Colegate, S.M. and R.J. Molyneux (Eds.). CRC Press, Boca Raton, FL., pp: 442-456.

Sharma, N., Sharma, V.K. . and Seo, S.Y. 2005. Screening of some medicinal plants for anti-lipase activity. $J$. Ethnopharmacol. 97, 453-456.

Shrestha, B., Basnett, H., Babu, V.D. and Patel, S.S. 2009. Anthelmintic and Antimicrobial activity of the chloroform extract of Pergularia daemia Forsk leaves. Adv. Pharmacol. Toxicol.10, 13-16.

Sleet, R.B. and Brendel, K. 1983. Improved methods for harvesting and counting synchronous populations of Artemia nauplii for use in developmental toxicology. Ecotoxicol. Environ. Saf. 7, 435-446.

Sofowara, A. 1982. Medicinal plants and traditional medicinal in Africa, Wiley, New York, pp. 256.

Soares, J.R., Dinis, T.C.P., Cunha, A.P. and Almeida, L.M. 1997. Antioxidant activities of some extracts of Thymus zygi. Free Radic. Res. 26, 469-478.

Sulaiman, M.R., Hussain, M.K., Zakaria, Z.A., Somchit, M.N., Moin, S., Mohamad. A.S. and Israf, D.A. 2008. Evaluation of the antinociceptive activity of Ficus deltoidea aqueous extract. Fitoterapia. 79, 557-561.

Thompson, D.P. and Geary, T.G. 1995. The structure and function of helminth surfaces. In: Biochemistry and Molecular Biology of Parasites. $1^{\text {st }}$ ed. Academic Press. New York. pp. 203-232.

Vanhaecke, P., Persoone, G., Claus, C. and Sorgeloos, P. 1981. Proposal for a short-term toxicity test with Artemia nauplii. Ecotoxicol. Environ. Saf. 5, 382-387. 